\title{
PENGARUH GAYA KEPEMIMPINAN, KOMPLEKSITAS TUGAS, TIME BUDGET PRESSURE, DAN KOMITMEN ORGANISASI TERHADAP KEPUASAN KERJA AUDITOR PADA KAP DI YOGYAKARTA
}

\author{
INFLUENCE OF LEADERSHIP STYLE, COMPLEXITY OF THE TASK, \\ TIME BUDGET PRESSURE, AND ORGANIZATIONAL COMMITMENT ON \\ JOB SATISFACTION OF AUDITORS ON REGISTERED PUBLIC \\ ACCOUNTANT OFFICE IN YOGYAKARTA
}

\author{
Divie Dantha Dewi \\ Prodi Akuntansi Universitas Negeri Yogyakarta \\ diviedantha@yahoo.com
}

Sukirno

Staf Pengajar Prodi Akuntansi Universitas Negeri Yogyakarta

Fakultas Ekonomi Universitas Negeri Yogyakarta

\begin{abstract}
ABSTRAK
Penelitian ini bersifat ex-post facto dan kausal komparatif yang bertujuan untuk mengetahui: (1) pengaruh Gaya kepemimpinan terhadap Kepuasan Kerja Auditor, (2) pengaruh Kompleksitas Tugas terhadap Kepuasan Kerja Auditor, (3) pengaruh Time budget pressure terhadap Kepuasan Kerja Auditor,(4) pengaruh Komitmen Organisasi terhadap Kepuasan Kerja Auditor, dan (5) pengaruh Gaya Kepemimpinan, Kompleksitas Tugas, Time budget pressure, dan Komitmen Organisasi secara bersama-sama terhadap Kepuasan Kerja Auditor. Populasi penelitian ini adalah auditor yang bekerja pada Kantor Akuntan Publik di Yogyakarta sebanyak 131 orang. Sampel yang digunakan pada penelitian ini adalah auditor yang berjumlah 49 responden pada 7 Kantor Akuntan Publik di Yogyakarta. Teknik pengumpulan data dilakukan dengan menggunakan kuesioner atau angket. Data yang terkumpul dianalisis dengan menggunakan uji asumsi klasik, regresi sederhana, dan regresi berganda. Hasil penelitian ini menunjukkan bahwa: (1) Terdapat pengaruh positif dan signifikan Gaya kepemimpinan terhadap Kepuasan Kerja Auditor yang ditunjukkan dengan nilai $r_{(x 1 y)}^{2}$ sebesar $0,319, t_{\text {hitung }}=4,691>t_{\text {tabel }}=$ 1,684 dan dengan signifikansi $(0,000<0,050)$, (2) Terdapat pengaruh negatif dan signifikan Kompleksitas Tugas terhadap Kepuasan Kerja Auditor yang ditunjukkan dengan nilai $R_{(x 2 y)}^{2}=0,233, t_{\text {hitung }}=-3,670>t_{\text {tabel }}=1,684$ dan dengan signifikansi $(0,000<$ 0,050), (3) Terdapat pengaruh negatif dan signifikan Time Budget Pressure terhadap Kepuasan Kerja Auditor. yang ditunjukkan dengan nilai $\mathrm{R}_{(\mathrm{x} 3 \mathrm{y})}=0,414, \mathrm{t}_{\text {hitung }}=-5,766>$ $\mathrm{t}_{\text {tabel }}=1,684$ dan dengan signifikansi $(0,000<0,050)$, (4) Terdapat pengaruh positif dan signifikan Komitmen Organisasi terhadap Kepuasan Kerja Auditor yang ditunjukkan dengan nilai $\mathrm{R}_{(\mathrm{x} 4 \mathrm{y})}^{2}=0,410, \mathrm{t}_{\text {hitung }}=5,711>\mathrm{t}_{\text {tabel }}=1,684$ dan dengan signifikansi $(0,000$ $<0,050)$, (5) Terdapat pengaruh Gaya Kepemimpinan, Kompleksitas Tugas, Time Budget Pressure, dan Komitmen Organisasi secara bersama-sama terhadap Kepuasan Kerja Auditor yang ditunjukkan dengan nilai $\mathrm{R}_{\mathrm{y}(\mathrm{x} 1 \times 2 \times 3 \times 4)}$ sebesar 0,845 , nilai $\mathrm{R}_{\mathrm{y}(\mathrm{x} 1 \times 2 \times 3 \times 4)}^{2}$ sebesar 0,714 , harga $F_{\text {hitung }}=27,482>F_{\text {tabel }}=2,606$, nilai signifikansi $(0,000<0,050)$. Dengan demikian, keseluruhan hasil analisis ini mendukung hipotesis yang diajukan.

Kata Kunci : Gaya Kepemimpinan, Kompleksitas Tugas, Time Budget Pressure, Komitmen Organisasi, dan Kepuasan Kerja Auditor
\end{abstract}




\title{
JURNAL NOMINAL / VOLUME II NOMOR II / TAHUN 2013
}

\begin{abstract}
This research is an ex-post facto causal comparative and aimed to determine: (1) the influence of leadership style on Job Satisfaction Auditor, (2) the influence of Complexity of the task on Job Satisfaction Auditor, (3) the influence of Time budget pressure on Job Satisfaction Auditor, (4) the influence of Organizational Commitment on Job Satisfaction Auditor, and (5) the influence of leadership style, Complexity of the Task, Time Budget Pressure, and Organizational Commitment together on Job Satisfaction Auditor. The study population was auditor who worked on Registered Public Accountant offices in Yogyakarta as many as 131 people. The sample used in this study is that the auditor amounted to 49 respondents in 7 Registered Public Accounting Offices in Yogyakarta. Data was collected using questionnaire. Data were analyzed by using the classical assumption test, simple regression, and multiple regression. The results showed that: (1) There is a positive and significant effect of leadership style on Job Satisfaction Auditor. Indicated by the value of $r 2$ (x1y) of 0.319, tcount $=4.691>$ ttable $=1.684$ and the significant $(0.000<0.050)$, (2) There is a negative and significant effect of Complexity of the task on Job Satisfaction Auditor. Indicated by the value R2 $(x 2 y)=0.233$, tcount $=-$ $3.670>$ ttable $=1.684$ and the significant $(0.000<0.050)$, (3) There is a negative and significant effect of Time budget pressure on Job Satisfaction Auditor. Indicated by the value of $R 2(x 3 y)=0.414$, tcount $=-5.766>$ ttable $=1.684$ and the significant $(0.000$ $<0.050)$, (4) There is a positive and significant impact on Job Satisfaction Organizational Commitment Auditor. Indicated by the value of $R 2(x 4 y)=0.410$, tcount $=5.711>$ ttable $=1.684$ and the significance $(0.000<0.050)$, (5) There is the influence of leadership style, Complexity of the task, Time budget pressure, and Organizational Commitment together to Satisfaction Auditors work. Indicated by Ry (X1X2 X3X4) of 0.845, the value $R 2 y(X 1 X 2 X 3 X 4)$ of 0.714, Fcount $=27.482>$ Ftable $=2.606$, significant value $(0.000$ $<0.050)$. Because of this, the overall results of this analysis support the hypothesis.
\end{abstract}

Keywords: Leadership Style, Complexity of the task, Time Budget Pressure, Organizational Commitment, and Job Satisfaction Auditor

\section{A. PENDAHULUAN}

Semakin berkembangnya profesi auditor di Indonesia menyebabkan jasa akuntan publik mulai diperlukan dan berkembang. Akuntan dalam hal ini adalah auditor yaitu suatu profesi yang salah satu tugasnya melaksanakan audit terhadap laporan keuangan sebuah perusahaan dan memberikan opini atau pendapat terhadap saldo akun dalam laporan keuangan.Catatan perkembangan jumlah akuntan di Indonesia tidak menunjukan angka yang lebih baik apabila dibandingkan dengan perkembangan jumlah akuntan publik di negara-negara berkembang lainnya. Dari data yang diambil dari Ikatan Akuntan Publik Indonesia (IAPI) tahun 2012 saat ini jumlah akuntan publik hanya mencapai 1500an orang, sedangkan Filipina dan Singapura memiliki lebih dari 20.000 akuntan publik. 
Minimnya jumlah akuntan di Indonesia disebabkan oleh beberapa faktor diantaranya kurangnya minat masyarakat untuk menjadi akuntan publik. Selain itu masalah yang lazim dihadapi oleh profesi akuntan publik yaitu tingkat perpindahan karyawan (turnover) yang sangat tinggi di KAP. Penelitian sebelumnya yang dilakukan oleh Suwandi dan Indriantoro (1999) telah berhasil mengidentifikasi proses keinginan berpindah, yang berhubungan dengan anteseden dan konsekuensi dari ketidakamanan kerja. Pada lingkungan profesi akuntan publik sendiri, turnover yang dihadapi KAP telah didokumentasikan dengan baik lewat berbagai literatur profesional dan akademik berbagai penelitian untuk mengidentifikasi berbagai faktor yang mempengaruhi turnover akuntan publik juga telah dilakukan. Secara umum, hasil dari berbagai penelitian tersebut menyarankan bahwa komitmen organisasional dan kepuasan kerja merupakan anteseden (variabel pendahulu) dari keinginan akuntan untuk mencari alternatif pekerjaan lain (Agus Arianto, 2001).

Kepuasan kerja merupakan salah satu faktor penting yang mempengaruhi kepuasan hidup karena sebagian besar waktu manusia dihabiskan di tempat mereka kerja. Menurut Handoko (1988) Kepuasan kerja (job satisfaction) adalah keadaan emosional yang menyenangkan atau tidak menyenangkan dengan mana para karyawan memandang pekerjaan. Tingkat kepuasan kerja masing-masing individu berbeda-beda sesuai dengan ukuran standar kepuasan individu tersebut. Hal ini disebabkan adanya perbedaan masing-masing individu dalam menilai tingkat kepuasan kerja, karena dengan semakin banyak aspekaspek pada pekerjaan yang sesuai dengan keinginan individu tersebut, maka semakin tinggi tingkat kepuasan yang dirasakan dan sebaliknya akan semakin rendah tingkat keinginan untuk berpindah kerja. Hal ini sesuai dengan pendapat Mangkunegara (2001) yang mengatakan bahwa kepuasan kerja berhubungan dengan variabel-variabel seperti turnover, tingkat absensi, umur, tingkat pekerjaan dan ukuran organisasi perusahaan.

Gaya kepemimpinan adalah perilaku atau cara yang dipilih dan dipergunakan pemimpin dalam mempengaruhi pikiran, perasaan, sikap, dan perilaku para anggota organisasi/bawahan (Nawawi, 2003). Banyak penelitian dan literatur yang menyebutkan bahwa gaya kepemimpinan dipandang sebagai salah satu 


\section{JURNAL NOMINAL / VOLUME II NOMOR II / TAHUN 2013}

faktor yang mempengaruhi kepuasan kerja. Kesuksesan organisasi dalam mencapai tujuan dan sasaran juga dipengaruhi oleh gaya kepemimpinan pemimpin suatu organisasi tersebut.

Dalam melaksanakan tugasnya auditor seringkali dihadapkan dengan sejumlah tugas-tugas yang kompleks, rumit, banyak juga saling berkaitan antara satu dengan yang lainnya. Kompleksitas audit pada dasarnya adalah tentang persepsi individu yaitu tentang kesulitan suatu tugas audit, sulit bagi seseorang namun bisa mudah bagi orang lain (Restu dan Indriantoro, 2000). Tingginya kompleksitas penugasan ini menuntut auditor untuk terus meningkatkan kemampuan daya pikir dan kesabaran dalam penyelesaian tugas, karena kompleksitas tugas merupakan tugas yang tidak terstruktur, membingungkan, dan sulit (Sanusi dan Iskandar, 2007).

Selain kompleksitas tugas faktor yang mempengaruhi tingkat kepuasan kerja auditor adalah tekanan anggaran waktu atau time budget pressure. Tekanan anggaran waktu atau time budget pressure adalah keadaan yang menunjukkan auditor dituntut untuk melakukan efisiensi terhadap anggaran waktu yang telah disusun atau terdapat pembahasan waktu anggaran yang sangat ketat dan kaku (Sososutikno, 2003). Hal ini tidak bisa lepas dari pekerjaan auditor, karena auditor seringkali bekerja dalam keterbatasan waktu. Tuntutan laporan yang berkualitas dengan anggaran waktu terbatas tentu saja merupakan tekanan tersendiri bagi auditor. Oleh karena itu, tekanan anggaran waktu juga dapat mempengaruhi kepuasan kerja seorang auditor.

Kepuasan kerja juga dipengaruhi oleh peningkatan kinerja auditor dalam rangka pencapaian tujuan perusahaan. Keberhasilan dan kinerja seseorang banyak ditentukan oleh tingkat kompetensi, dan tak dan lepas dari sejauh mana komitmen individu tersebut terhadap bidang yang ditekuninya. Menurut Robbins (2001) komitmen pada organisasi diartikan sejauh mana seorang karyawan memihak pada suatu organisasi tertentu dan tujuan-tujuannya, serta berniat memelihara keanggotaan dalam organisasi tersebut. Komitmen pada organisasi yang tinggi berarti mengaitkan diri ke organisasi yang memperkerjakan. Teori yang melandasi hubungan antara kepuasan kerja dengan komitmen organisasi adalah teori harapan (expectancy theory) yang dikemukakan oleh Victor $\mathrm{H}$. 
Vroom (1964) dalam Hasibuan (1999:116) yang menyatakan bahwa kekuatan yang memotivasi seseorang untuk bekerja giat dalam mengerjakan pekerjaannya tergantung dari hubungan timbal balik antara apa yang ia inginkan dan butuhkan dari hasil pekerjaan itu. Berapa besar ia yakin perusahaan akan memberikan pemuasan bagi keinginannya sebagai imbalan atas usaha yang dilakukannya itu. Bila keyakinan yang diharapkan cukup besar untuk memperoleh kepuasannya maka ia akan bekerja keras dan berkomitmen tinggi kepada perusahaan atau organisasi dan sebaliknya.

Komitmen organisasi menjadi perhatian penting dalam banyak penelitian karena memberikan dampak signifikan terhadap perilaku kerja seperti kinerja, kepuasan kerja, absensi karyawan dan juga turnover karyawan. Karena diharapkan dengan komitmen yang baik akan berdampak positif terhadap kinerja suatu pekerjaan karena karyawan tersebut dapat termotivasi dan mempunyai rasa ikut memilki organisasi dimana dia bekerja. Jika auditor merasa jiwanya terikat dengan nilai-nilai organisasional yang ada maka dia akan merasa senang dalam bekerja, sehingga tingkat kepuasan kerja meningkat dan kinerjanya akan semakin baik. Komitmen organisasi memberi titik berat secara khusus terhadap kekontinuan faktor komitmen yang menyarankan keputusan untuk tetap atau meninggalkan pekerjaan atau organisasi yang pada akhirnya tergambar dalam statistik ketidakhadiran dan keinginan untuk pindah kerja (Mathis dan Jackson, 2001:100). Karena apabila seorang karyawan sudah terpenuhi segala kebutuhannya maka dia akan mencapai kepuasan kerja dan memiliki komitmen terhadap perusahaan. Tingginya komitmen karyawan dapat mempengaruhi usaha suatu perusahaan secara positif. Dengan adanya komitmen yang tinggi akan membuat karyawan mendukung semua kegiatan perusahaan secara aktif, hal ini berarti akan memacu karyawan untuk bekerja lebih produktif. Lebih luas lagi Mathis dan Jackson (2001:100) juga mengungkapkan bahwa karyawan yang relatif puas dengan pekerjaannya akan lebih berkomitmen pada organisasi dan karyawan yang berkomitmen terhadap organisasi lebih mungkin mendapat kepuasan yang lebih besar.

Kepuasan kerja merupakan perbandingan hasil kerja yang dicapai dengan standar yang telah ditentukan oleh perusahaan. Dimana kepuasan kerja menjadi 
salah satu faktor yang mempengaruhi kinerja seseorang. Terlebih dengan pekerjaan auditor yang rumit dan kompleks dimana auditor senantiasa dituntut untuk menghasilkan audit yang berkualitas. Karena itu kepuasan kerja merupakan satu hal yang penting untuk menunjang kinerja auditor, dengan kondisi lingkungan yang baik diharapkan auditor akan merasa lebih nyaman dalam pekerjaannya dan tentunya hal ini akan berdampak pada meningkatnya kinerja auditor itu sendiri.

Berdasarkan penjelasan di atas, peneliti tertarik untuk melakukan penelitian mengenai Kepuasan Kerja Auditor dan bagaimana pengaruh Gaya Kepemimpinan, Kompleksitas tugas, Time Budget Pressure dan Komitmen Organisasi terhadap Kepuasan Kerja Auditor yang bekerja di Kantor Akuntan Publik Yogyakarta.

Tujuan dari penelitian ini adalah mengetahui pengaruh Gaya Kepemimpinan terhadap Kepuasan Kerja Auditor, pengaruh Kompleksitas Tugas terhadap Kepuasan Kerja Auditor, pengaruh Time Budget Pressure terhadap Kepuasan Kerja Auditor, pengaruh Komitmen Organisasi terhadap Kepuasan Kerja Auditor, dan pengaruh Gaya Kepemimpinan, Kompleksitas Tugas, Time Budget Pressure dan Komitmen Organisasi secara bersama-sama terhadap Kepuasan Kerja Auditor. Adapun manfaat dari penelitian ini adalah dapat digunakan sebagai masukan untuk menyusun suatu kebijakan dan pertimbangan dalam meningkatkan kepuasan kerja auditor pada sebuah KAP.

\section{B. METODE PENELITIAN}

\section{Jenis Penelitian}

Jenis penelitian ini adalah penelitian kausal komparatif yang merupakan tipe penelitian ex post facto yaitu dengan mengidentifikasi fakta atau peristiwa sebagai variabel yang dipengaruhi (variabel dependen) dan melakukan penyelidikan terhadap variabel yang mempengaruhi (variabel independen). Pendekatan yang digunakan dalam penelitian ini adalah pendekatan kuantitatif. 


\section{Waktu dan Tempat Penelitian}

Penelitian ini dilakukan di Kantor Akuntan Publik yang berada di Daerah Istimewa Yogyakarta. Waktu penelitian ini dilaksanakan selama dua bulan yaitu mulai bulan Maret 2013 sampai Mei 2013.

\section{Populasi dan Sampel Penelitian}

Populasi dari penelitian ini adalah seluruh auditor yang bekerja di Kantor Akuntan Publik (KAP) di Daerah Istimewa Yogyakarta. Sampel berjumlah 49 responden dengan teknik pengambilan sampel dalam penelitian ini menggunakan cara purposive sampling, yaitu responden diambil secara sengaja berdasarkan tujuan tertentu dari penelitian. Metode ini diterapkan karena beberapa pertimbangan yaitu keterbatasan waktu, tenaga dan dana, sehingga tidak dapat mengambil sampel yang besar dan jauh (Suharsimi Arikunto, 2006). Pertimbangan tertentu tersebut adalah responden yang memenuhi kriteria yaitu hanya auditor yang bekerja pada Kantor Akuntan Publik di Yogyakarta.

\section{Definisi Operasional Variabel Penelitian}

Variabel dependen pada penelitian ini adalah kepuasan kerja auditor. Kepuasan Kerja Auditor dalam penelitian ini kepuasan kerja auditor yang dimaksud adalah bagaimana seorang auditor tersebut memandang pekerjaan mereka dan kepuasan kerja tersebut mencerminkan perasaan auditor tersebut terhadap pekerjaannya yang hal itu dapat dilihat dari sikap positif auditor terhadap pekerjaannya dan segala sesuatu yang dihadapi di lingkungan kerjanya.

Sedangkan variabel independen terdiri dari Gaya Kepemimpinan, Kompleksitas Tugas, Time Budget Pressure dan Komitmen Organisasi.

Gaya Kepemimpinan yang dimaksud dalam penelitian ini adalah perilaku atau cara memimpin yang digunakan pemimpin dalam mempengaruhi pikiran, perasaan, sikap, dan perilaku para auditor atau bawahan dalam menjalankan organisasinya yaitu Kantor Akuntan Publik agar segala tujuan dari organisasi akuntan publik tersebut dapat tercapai. Konsep Kompleksitas Tugas dalam penelitian ini adalah mengenai jumlah tugas 
yang diberikan kepada auditor selama bekerja di Kantor Akuntan Publik hingga saat ini dan bagaimana pengaruhnya terhadap kepuasan kerja yang dirasakan oleh auditor. Time Budget Pressure yang dimaksud dalam penelitian ini adalah keadaan dimana auditor dituntut untuk melakukan efisiensi terhadap anggaran waktu yang telah disusun atau bisa dikatakan terdapat pembahasan waktu anggaran yang sangat ketat dan kaku. Komitmen Organisasi pada penelitian ini adalah sejauh mana seorang auditor berniat memelihara keanggotaan dalam organisasi dimana auditor bekerja, selain itu adanya dorongan dalam diri auditor tersebut untuk berbuat sesuatu agar dapat menunjang keberhasilan organisasi tempat bekerja dengan tujuan dan lebih mengutamakan kepentingan organisasi yang dalam hal adalah Kantor Akuntan Publik.

\section{Teknik Pengumpulan Data}

Teknik pengumpulan data yang digunakan dalam penelitian ini adalah menggunakan metode angket atau koesioner. Metode ini dilakukan melalui penyebaran kuesioner yang telah disusun secara terstuktur. Daftar pertanyaan dalam penelitian ini berupa pertanyaan tertutup karena alternatif-alternatif jawaban telah disediakan terkait tentang Gaya Kepemimpinan, Kompleksitas Tugas, Time Budget Pressure, dan Komitmen Organisasi serta Kepuasan Kerja Auditor. Penyebaran dan pengumpulan kuesioner dilakukan secara langsung oleh peneliti dengan cara mengantar kuesioner langsung ke KAP di wilayah Yogyakarta yang terdaftar pada direktori Ikatan Akuntan Indonesia (IAI).

\section{Uji Coba Instrumen}

\section{a. Uji Validitas}

Uji Validitas digunakan untuk mengetahui kelayakan butir-butir daftar pertanyaan dalam mendefinisikan suatu variabel.

\section{b. Uji Realibilitas}

Realibilitas merupakan ukuran suatu kestabilan dan konsistensi responden dalam menjawab hal yang berkaitan dengan konstruk 
pertanyaan yang merupakan dimensi suatu variabel dan disusun dalam bentuk kuesioner.

\section{Teknik Analisis Data}

Teknik analisis data yang digunakan dalam penelitian ini ada dua, yaitu.

\section{a. Uji Asumsi Klasik}

Uji asumsi klasik yang digunakan adalah sebagai berikut.

1) Uji Normalitas

Uji normalitas bertujuan untuk menguji apakah dalam model regresi, variabel pengganggu atau residual memiliki distribusi normal.

2) Uji Linearitas

Uji linearitas digunakan untuk mengetahui apakah variabel independen dan variabel dependen dalam penelitian ini mempunyai hubungan yang linear jika kenaikan skor variabel independen diikuti kenaikan skor variabel dependen.

3) Uji Multikolinearitas

Uji multikolinearitas diperlukan untuk mengetahui ada tidaknya variabel independen yang memiliki kemiripan dengan variabel independen lain dalam satu model.

4) Uji Heteroskedastisitas

Uji heteroskedastisitas bertujuan untuk menguji apakah dalam model regresi terjadi ketidaksamaan variance dari residual satu pengamatan kepengamatan yang lain.

b. Uji Hipotesis

\section{1) Regresi sederhana}

Analisis ini digunakan menguji empat hipotesis berikut ini.

$\mathrm{H}_{1}$ : Terdapat pengaruh positif Gaya Kepemimpinan terhadap Kepuasan Kerja Auditor.

$\mathrm{H}_{2}$ : Terdapat pengaruh negatif Kompleksitas Tugas terhadap Kepuasan Kerja Auditor. 
$\mathrm{H}_{3}$ : Terdapat pengaruh negatif Time Budget Pressure terhadap Kepuasan Kerja Auditor.

$\mathrm{H}_{4}$ : Terdapat pengaruh positif Komitmen Organisasi terhadap Kepuasan Kerja Auditor.

\section{2) Regresi Berganda}

Analisis ini digunakan untuk menguji hipotesis kelima,yaitu.

$\mathrm{H}_{5}$ : Terdapat pengaruh Gaya Kepemimpinan, Kompleksitas Tugas, Time Budget Pressure, dan Komitmen Organisasi secara bersama-sama terhadap Kepuasan Kerja Auditor.

\section{HASIL PENELITIAN DAN PEMBAHASAN}

Berdasarkan hasil penelitian yang diperoleh, menggunakan Uji Asumsi Klasik, Regresi Sederhana dan Regresi Berganda hasil penelitian ini menunjukan bahwa:

Uji Normalitas dalam penelitian ini dikatakan berdistribusi normal, karena nilai sig > 0,050. Hasil Uji Linearitas pada penelitian ini bersifat linier karena nilai signifikansi tersebut lebih besar dari 0,05, sehingga dapat disimpulkan bahwa pengaruh masing-masing variabel independen terhadap variabel dependen bersifat linier.

Selanjutnya, pada hasil Uji Multikolinearitas pada penelitian ini, semua variabel memiliki nilai VIF yang kurang dari 10. Maka model regresi diyatakan bebas dari multikolinearitas. Pada pengujian Heteroskedastisitas dilakukan dengan cara melihat pola Scatterplot. Dari hasil penelitian ini terlihat titik-titik menyebar secara acak dan tidak membentuk pola yang jelas. Dengan demikian, dapat disimpulkan bahwa tidak terjadi heterokedastisitas dalam model regresi ini. 
Tabel 1. Uji Regresi Sederhana

\begin{tabular}{|c|c|l|l|}
\hline \multirow{2}{*}{ Variabel } & \multicolumn{2}{|c|}{ Nilai t } & \multirow{2}{*}{ Sig } \\
\cline { 2 - 3 } & hitung & tabel & \\
\hline $\mathrm{X}_{1}-\mathrm{Y}$ & 4,691 & 1,684 & 0,000 \\
$\mathrm{X}_{2}-\mathrm{Y}$ & $-3,670$ & 1,684 & 0,000 \\
$\mathrm{X}_{3}-\mathrm{Y}$ & $-5,766$ & 1,684 & 0,000 \\
$\mathrm{X}_{4}-\mathrm{Y}$ & 5,711 & 1,684 & 0,000 \\
\hline
\end{tabular}

Dari tabel uji regresi sederhana tersebut, dapat diketahui nilai koefisien regresi Gaya Kepemimpinan $\left(\mathrm{X}_{1}\right)$ sebesar 0,583 menunjukkan gaya kepemimpinan berpengaruh positif terhadap Kepuasan Kerja Auditor (Y). Hasil pengujian menunjukkan harga koefisien korelasir $_{(\mathrm{x} 1 \mathrm{y})} \operatorname{sebesar} 0,565$ dan nilai koefisien determinasi $r_{(x 1 y)}^{2}$ sebesar 0,319 artinya Gaya Kepemimpinan memiliki pengaruh terhadap Kepuasan kerja Auditor sebesar 31,9 \%. Dengan $\mathrm{t}_{\text {hitung }}$ sebesar 4,691 lebih besar dari $\mathrm{t}_{\text {tabel }}$ yaitu 1,684 dan nilai signifikansi lebih kecil dari level of significant $(0,000<0,050)$. menunjukkan pengaruh Gaya Kepemimpinan $\left(\mathrm{X}_{1}\right)$ terhadap Kepuasan Kerja Auditor (Y) adalah signifikan. Berdasarkan pengujian tersebut dapat disimpulkan terdapat pengaruh positif dan signifikan Gaya Kepemimpinan $\left(\mathrm{X}_{1}\right)$ terhadap Kepuasan Kerja Auditor (Y) pada Kantor Akuntan Publik di Daerah Istimewa Yogyakarta sehingga Hipotesis diterima.

Gaya Kepemimpinan dipandang sebagai salah satu indikator penting. kesuksesan suatu organisasi dalam mencapai tujuan. Gaya Kepemimpinan yang lebih baik dapat lebih meningkatkan Kepuasan Kerja Auditor. Jika kepuasan kerja pada suatu organisasi itu buruk, maka KAP tersebut perlu melakukan evaluasi atau melihat apakah gaya kepemimpinan yang diterapkan di dalam organisasi tersebut telah cocok dengan auditor atau tidak.

Dari hasil analisis menggunakan regresi sederhana diperoleh nilai koefisien regresi Kompleksitas Tugas $\left(\mathrm{X}_{2}\right)-0,382$ menunjukkan Kompleksitas Tugas berpengaruh negatif terhadap kepuasan kerja auditor (Y). Hasil pengujian menunjukkan nilai koefisien korelasi $r_{(x 2 y)}$ sebesar $-0,472$ dan nilai koefisien determinasi $r_{(x 2 y)}^{2}$ sebesar 0,233. Dengan nilai $t_{\text {hitung }}$ lebih besar dari 
$\mathrm{t}_{\text {tabel }}$ yaitu 1,684 dan nilai signifikansi lebih kecil dari level of significant $(0,000$ $<0,050)$, menunjukkan pengaruh Kompleksitas Tugas $\left(\mathrm{X}_{2}\right)$ terhadap (Y) adalah signifikan. Berdasarkan hal tersebut disimpulkan terdapat pengaruh negatif dan signifikan Kompleksitas Tugas terhadap Kepuasan Kerja Auditor pada KAP di Yogyakarta.

Semakin tinggi tingkat kompleksitas suatu penugasan yang diberikan kepada para auditor di sebuah KAP, maka akan semakin menurunnya kepuasan kerja yang dirasakan auditor tersebut. Begitu juga sebaliknya. Penugasan menjadi hal yang wajar bagi auditor, tetapi semakin banyak dan kompleknya tugas yang diberikan, maka akan berdampak pada kepuasan kerja yang dirasakan auditor.

Dari hasil analisis menggunakan regresi sederhana diperoleh nilai koefisien regresi Time Budget Pressure $\left(\mathrm{X}_{3}\right)$-0,580 menunjukkan Time Budget Pressure berpengaruh negatif terhadap Kepuasan Kerja Auditor (Y). Hasil pengujian menunjukkan nilai koefisien korelasi $r_{(x 3 y)}-0,644$ dan nilai koefisien determinasi $r_{(x 3 y)}^{2}$ sebesar 0,414. thitung sebesar -5,766 menunjukkan lebih besar dari ttabel yaitu 1,684 dan nilai signifikansi lebih kecil dari level of significant $(0,000<0,050)$ sehingga menunjukkan pengaruh Time Budget Pressure (X3) terhadap (Y) adalah signifikan.

Berdasarkan hal tersebut dapat disimpulkan terdapat pengaruh negatif dan signifikan Time Budget Pressure terhadap Kepuasan Kerja Auditor pada Kantor Akuntan Publik di Yogyakarta. Stress yang tinggi kerap dihadapi auditor, karena auditor selalu dihadapkan dengan pekerjaan yang banyak dan kompleks dimana auditor selalu dituntut bekerja dalam keterbatasan waktu, dan tentunya menjadi tekanan tersendiri bagi auditor.

Hasil pengujian Komitmen Organisasi menunjukkan nilai koefisien korelasi $r_{(x 4 y)}$ sebesar 0,640 dan nilai koefisien determinasi $r_{(x 4 y)}^{2}$ sebesar 0,410. $\mathrm{t}_{\text {hitung }}$ menunjukkan lebih besar dari $\mathrm{t}_{\text {tabel }}$ yaitu 1,684 dan nilai signifikansi lebih kecil dari level of significant $(0,000<0,050)$ sehingga menunjukkan pengaruh Komitmen Organisasi $\left(\mathrm{X}_{4}\right)$ terhadap $(\mathrm{Y})$ adalah signifikan. Berdasarkan hal tersebut dapat disimpulkan terdapat pengaruh positif dan signifikan Komitmen 
Organisasi terhadap Kepuasan Kerja Auditor pada Kantor Akuntan Publik di Daerah Istimewa Yogyakarta.

Hal ini mengindikasikan bahwa semakin tinggi tingkat Komitmen Organisasi yang dirasakan oleh auditor maka akan semakin meningkatkan Kepuasan Kerja Auditor, dan begitu pula sebaliknya.

Tabel 2. Uji Regresi Berganda

\begin{tabular}{|c|l|l|l|}
\hline Variabel & \multicolumn{2}{|c|}{ Nilai F } & \multirow{2}{*}{ Sig } \\
& Hitung & tabel & \\
\hline (Constan) & & & \\
\hline $\mathrm{X}_{1}$ & & & \\
\cline { 1 - 1 } $\mathrm{X}_{2}$ & \multirow{2}{*}{27,482} & 2,606 & \multirow{2}{*}{0,000} \\
\cline { 1 - 1 } $\mathrm{X}_{3}$ & & & \\
\cline { 1 - 1 } $\mathrm{X}_{4}$ & & & \\
\hline
\end{tabular}

Dari hasil analisis menggunakan regresi berganda diperoleh nilai koefisisen determinasi ${ }_{2 y(x 1 \times 2 \times 3 \times 4)}$ sebesar 0,714 artinya secara bersama- sama memiliki pengaruh terhadap Kepuasan Kerja Auditor sebesar 71,4\% dan sisanya 28,6\% dijelaskan oleh variabel lain yang tidak diteliti. Besarnya $f$ hitung $>\mathrm{f}$ tabel dengan signifikasi $(0,000<0,005)$ dapat disimpulkan bahwa terdapat pengaruh bersama-sama dan signifikan Gaya Kepemimpinan, Kompleksitas Tugas, Time Budget Pressure, dan Komitmen Organisasi secara bersama-sama terhadap Kepuasan Kerja Auditor pada Kantor Akuntan Publik di Yogyakarta sehingga hipotesis kelima diterima. Semakin banyak Gaya Kepemimpinan, dan Komitmen Organisasi seorang akan semakin meningkatkan Kepuasan Kerja Auditor ataupun sebaliknya. Namun, jika semakin tinggi Kompleksitas Tugas dan Time Budget Pressure dalam melaksanakan pekerjaan maka akan berdampak pada menurunnya kepuasan kerja auditor.

\section{PENUTUP}

\section{Simpulan}

Berdasarkan data yang diperoleh dan hasil analisis, maka kesimpulan dari penelitian ini sebagai berikut: 
a. Gaya Kepemimpinan berpengaruh positif dan signifikan terhadap Kepuasan Kerja Auditor pada Kantor Akuntan Publik di Daerah Istimewa Yogyakarta. Hal ini dapat dibuktikan melalui analisis regresi sederhana diperoleh nilai koefisien korelasi $\mathrm{r}_{(\mathrm{x} 1 \mathrm{y})}$ sebesar 0,565 dan nilai koefisien determinasi $r_{(x 1 y)}^{2}$ sebesar 0,319 atau Gaya Kepemimpinan memiliki pengaruh 31,9\% terhadap Kepuasan Kerja Auditor dengan $t_{\text {hitung }}$ sebesar 4,691 lebih besar dari $t_{\text {tabel }}$ yaitu 1,684 dan nilai signifikansi lebih kecil dari level of significant $(0,000<0,050)$. Persamaan garis regresinya adalah $\mathrm{Y}=$ $19,765+0,583 X_{1}$. Dapat disimpulkan bahwa semakin tinggi Gaya Kepemimpinan maka semakin tinggi Kepuasan Kerja Auditor.

b. Kompleksitas Tugas berpengaruh negatif dan signifikan terhadap Kepuasan Kerja Auditor pada Kantor Akuntan Publik di Daerah Istimewa Yogyakarta. Hal ini ditunjukkan melalui analisis regresi sederhana diperoleh nilai koefisien korelasi $\mathrm{r}_{(\mathrm{x} 2 \mathrm{y})}$ sebesar $-0,472$ dan nilai koefisien determinasi $\mathrm{r}_{(\mathrm{x} 2 \mathrm{y})}^{2}$ sebesar 0,233 atau Kompleksitas Tugas memiliki pengaruh 23,3\% terhadap Kepuasan Kerja Auditor. thitung sebesar -3,670 menunjukkan lebih besar dari ttabel yaitu 1,684 dan nilai signifikansi lebih kecil dari level of significant $(0,000<0,050)$. Persamaan garis regresinya adalah $\mathrm{Y}=41,648-0,382 \mathrm{X}_{2}$. Dapat disimpulkan bahwa semakin tinggi Kompleksitas Tugas maka semakin rendah Kepuasan Kerja yang dirasakan auditor.

c. Time Budget Pressure berpengaruh negatif dan signifikan terhadap kepuasan kerja auditor pada Kantor Akuntan Publik di Daerah Istimewa Yogyakarta. Hal ini ditunjukkan melalui analisis regresi sederhana diperoleh nilai koefisien korelasi $r_{(x 3 y)}$ sebesar $-0,644$ dan nilai koefisien determinasi $r_{(x 3)}^{2}$ sebesar 0,414. Dengan thitung -5,766 menunjukkan lebih besar dari ttabel yaitu 1,684 dan nilai signifikansi lebih kecil dari level of significant $(0,000<0,050)$ Persamaan garis regresinya adalah $\mathrm{Y}=44,432$ 0,580 $\mathrm{X}_{2}$. Dapat disimpulkan bahwa semakin tinggi Time Budget Pressure maka semakin menurun Kepuasan Kerja yang dirasakan auditor.

d. Komitmen Organisasi berpengaruh positif dan signifikan terhadap Kepuasan Kerja Auditor pada Kantor Akuntan Publik di Daerah Istimewa 
Yogyakarta. Hal ini ditunjukkan melalui analisis regresi sederhana diperoleh nilai koefisien korelasi $\mathrm{r}_{(\mathrm{x} 4 \mathrm{y})}$ sebesar 0,640 dan nilai koefisien determinasi $\mathrm{r}_{(\mathrm{x} 4 \mathrm{y})}^{2}$ sebesar 0,410 atau komitmen organisasi memiliki pengaruh $41 \%$ terhadap Kepuasan Kerja Auditor dengan $t_{\text {hitung }}$ sebesar 5,711 lebih besar dari $t_{\text {tabel }}$ yaitu 1,684 dan nilai signifikansi lebih kecil dari level of significant $(0,000<0,050)$ yang

menunjukkan pengaruh Komitmen Organisasi $\left(\mathrm{X}_{4}\right)$ terhadap Kepuasan Kerja Auditor (Y) adalah signifikan. Persamaan garis regresinya adalah Y $=14,928+0,571 \mathrm{X}_{4}$. Dapat disimpulkan bahwa semakin tinggi rasa Komitmen Organisasi maka akan semakin tinggi tingkat Kepuasan Kerja yang dirasakan auditor.

e. Gaya Kepemimpinan, Kompleksitas Tugas, Time Budget Pressure, dan Komitmen Organisasi berpengaruh signifikan secara bersama-sama terhadap Kepuasan Kerja Auditor pada Kantor Akuntan Publik di Daerah Istimewa Yogyakarta. Hal ini dibuktikan melalui analisis regresi berganda didapatkan nilai koefisien korelasi $\operatorname{Ry}(\times 1 \times 2 \times 3 \times 4)$ sebesar 0,845 dan nilai koefisisen

Determinasi ${ }_{2 \mathrm{y}(\mathrm{x} 1 \times 2 \times 3 \times 4)}^{\mathrm{n}}$ sebesar 0,714 artinya secara bersama-sama memiliki pengaruh 71,4 \% terhadap Kepuasan Auditor serta sisanya 28,5 \% dijelaskan oleh variabel lain yang tidak diteliti. Fhitung sebesar 27,482 lebih besar dari Ftabel yaitu 2,606. Selain itu signifikansi lebih kecil daripada level of significant $(0,000<0,050)$. Persamaan garis regresinya $\mathrm{Y}=23,057+0,290 \mathrm{X}_{1}-0,253 \mathrm{X}_{2^{-}}$ $0,196 X_{3}+0,373 X_{4}$ maka dapat disimpulkan semakin besar Gaya Kepemimpinan, Komitmen Organisasi maka akan semakin meningkat pula Kepuasan Kerja yang dirasakan auditor ataupun sebaliknya. Namun, semakin banyak tingkat Kompleksitas Tugas dan Time Budget Presure yang dirasakan auditor, maka Kepuasan Kerja yang dirasakan auditor pun semakin menurun.

\section{Saran}

Berdasarkan kesimpulan yang telah dikemukakan di atas, maka dapat diberikan saran-saran sebagaiberikut. 


\section{a. Bagi Auditor}

Auditor perlu meningkatkan rasa memiliki terhadap organisasi. Selain itu auditor diharapkan dapat lebih mengelola waktu dengan baik mengingat pekerjaan auditor yang senantiasa kompleks dan dalam keterbatasan waktu.

\section{b. Bagi Kantor Akuntan Publik}

Sebaiknya lebih memperhatikan hal-hal yang mempengaruhi kepuasan kerja auditor karena dengan tingkat kepuasan kerja yang tinggi tentunya akan berdampak pula pada kinerja auditor yang semakin optimal dan membuat auditor tetap bertahan untuk bekerja di kantor akuntan publik, dan hal tersebut dapat mengurangi banyaknya turnover yang terjadi di lingkungan KAP.

\section{c. Bagi Peneliti Selanjutnya}

a. Untuk penelitian selanjutnya sebaiknya menggunakan penelitian populasi, dengan penelitian populasi maka penelitian ini akan maksimal

b. Diharapkan pada penelitian selanjutnya dapat menggunakan instansi lain sebagai obyek penelitian, misal BPK, BPKP, maupun Kantor Akuntan Publik yang mempunyai skala ukuran KAP besar.

\section{E. DAFTAR PUSTAKA}

Agus Rianto Toly. (2001).”Analisis Faktor-Faktor yang Mempengaruhi Turnover Intentions Pada Staf Kantor AkuntanPublik: Studi Empiris Terhadap Kantor Akuntan Publik di Jawa Timur". Jurnal Ekonomi. Universitas Kristen Petra.

Andin Prasita dan Priyo Hari Adi. (2007)."Pengaruh Kompleksitas Audit dan Tekanan Anggaran Waktu terhadap Kualitas Audit dengan Moderasi Pemahaman terhadap Sistem Informasi”.Skripsi. Fakultas Ekonomi. Universitas Kristen Satya Wacana.

Bhuono Agung Nugroho. (2005). Strategi Jitu Memilih Metode Statistik Penelitian Dengan SPSS. Yogyakarta: CV Andi Offset. 
Gibson James. L, Ivancevich John M dan Donnely James H, Jr. (1996). Organisasi: Perilaku, Struktur dan Proses. Terjemahan. Jilid 1. Penerbit Binarupa Aksara, Jakarta.

Hani Handoko T. (1988). Manajemen Personalia dan Sumber Daya Manusia. Penerbit BPFE Yogyakarta

Haryadi Sarjono dan Winda Julianita. (2011).SPSS vs LISREL (Sebuah Pengantar, Aplikasi untuk Riset). Jakarta: Salemba Empat.

Imam Ghozali. (2011). Aplikasi Analisis Multivariat Dengan Program IBM SPSS 19. Semarang: UNDIP.

Malayu S.P. Hasibuan. (1999). Organisasi dan Motivasi. Jakarta: Bumi Aksara.

Malayu S.P Hasibuan. (2005). Manajemen sumber Daya Manusia (Edisi Revisi), Jakarta: Bumi Aksara.

Mangkunegara,P.A.A.A.(2001). Manajemen Sumber Daya Manusia Perusahaan. Bandung: PT Remaja Rosdakarya.

Marganingsih A, dan Martani D. (2010). "Anteseden Komitmen organisasi dan Motivasi: Konsekuensinya Terhadap Kinerja Auditor Intern Pemerintah”. Jurnal Akuntansi Keuangan Indonesia. Vol 7 No. 1

Muhammad Fauzan Baihaqi. (2010). "Pengaruh Gaya Kepemimpinan terhadap Kepuasan Kerja dan Kinerja dengan Komitmen Organisasi sebagai Variabel Intervening ”.Skripsi:Universitas Diponegoro

Nawawi, Hadari. (2003). Kepemimpinan Mengefektifkan Organisasi. Penerbit:

Universitas Gadjah Mada.Yogyakarta.

Restuningdiah, Nurika dan Nur Indriantoro. (2000). "Pengaruh Partisipasi terhadap Kepuasan Pemakai dalam Pengembangan Sistem Informasi dengan Kompleksitas Tugas, Kompleksitas Sistem, dan Pengaruh Pemakai sebagai Moderating Variable". Jurnal Riset Akuntansi Indonesia, Vol. 3, No. 2 : 119- 133

Robets L. Mathis dan John H. Jackson. (2001). Manajemen Sumber Daya 1.Edisi 9. Jakarta :Salemba empat.

Robbins, Stephen P. (2001).Perilaku organisasi Jilid 1. Jakarta:PT Prenhallindo

RM, Putra. (2012)." Analisis Faktor-Faktor yang Mempengaruhi Job Satisfaction Auditor yang Bekerja Pada Kantor Akuntan Publik di 
Jakarta".Skripsi.Fakultas Ekonomika dan Bisnis. Universitas Diponogoro.

Sanusi, ZM, Iskandar, TM dan June M. L. Poon. 2007. "Effect of Goal Orientation and Task Complexity on Audit Judgment Performance". Malaysian Accounting Review. pp. 123-139.

Sososutikno, Christina. (2003)."Hubungan Tekanan Anggaran Waktu dengan Perilaku Disfungsional serta Pengaruhnya terhadap Kualitas Audit”.Simposium Nasional Akuntansi VI. pp 1116-1124.

Suwandi, dan Nur Indriantoro.(1999)," Pengujian Model Turnover Pasewark dan Strawser: Studi Empiris pada lingkungan Akuntansi Publik", Jurnal riset Akuntansi Indonesia 2 , halaman 173-195.

Sugiyono.(2010). Metode Penelitian Bisnis. Bandung: CV Alfabeta.

Trisnaningsih, Sri. (2001). "Pengaruh komitmen terhadap Kepuasan Kerja Auditor Motivasi sebagai Variabel Intervening : Studi Empiris Terhadap Kantor Akuntan Publik di Jawa Timur”.Tesis.Univeritas Diponegoro Thoha, Miftah. (2001).Kepemimpinan dalam Manajemen SuatuPendekatan Perilaku.Jakarta: Raja Grafindo Persada.

Yukl, A.G. (1998). Kepemimpinan Dalam Organisasi. Edisi Bahasa Indonesia:

Yusuf Udaaya. Jakarta: Penerbit Prenhallindo

Yukl,Gary.(2005).Kepemimpinan dalam Organisasi. Edisi Kelima. Jakarta: Prenhallindo. 